\title{
Implementing Tasks in Primary English Education in Portugal
}

\author{
Maria Isabel Mendonça Orega. School of Education and Communication, University of Algarve
} and CETAPS

\author{
Recepción: 22/02/2019 | Aceptado: 30/04/2019 \\ Correspondencia a través de ORCID: María Isabel Mendonça \\ 0000-0001-9995-4127 \\ Citar: Mendonça Orega, MI (2019). Implementing Tasks in Primary English Education in \\ Portugal. ReiDoCrea - Monográfico sobre Perspectivas transnacionales en la enseñanza de \\ lenguas, 8(3), 128-140.
}

\begin{abstract}
This paper refers to the work of the students doing the Master's in Teaching English in Primary Education, taught at the University of Algarve. The study plan of the degree will be presented focusing on the components regarding observation in schools and the teaching practice, namely the courses Introduction to the Professional Practice, in the first year of the degree, and the Practicum in the first semester of the second year. A task-based approach is recommended in the main guiding documents, on both the teaching of English in general, and the Primary Education context, (Common European Framework of Reference for Languages, 2001; Cameron, 2001; Thomas \& Reinders, (eds.), 2010; Richards \& Rodgers, (3rd. ed.), 2014; Bygate, M. (2015). Nevertheless, most of the textbooks used in the schools offer few suggestions of tasks and focus on more traditional language activities. As a result, the teachers have a very important role in the implementation of a task-based approach. They are responsible for deciding on how to plan the lessons and how to think of the necessary changes and adaptations, in order to be able to work from a task-based perspective.
\end{abstract}

Keywords: Teacher Education, Task-based language Teaching

\section{Implementación de tareas en Educación Primaria en Portugal}

Resumen: Este artículo se refiere al trabajo de los estudiantes del Máster en Enseñanza del Inglés en Educación Primaria de la Universidad del Algarve. Se presentará el plan de estudios del grado enfocándose en los componentes relacionados con la observación en las escuelas y las prácticas, es decir, los cursos de Introducción a la Práctica Profesional, en el primer año de la licenciatura y el Prácticum en el primer semestre del segundo año. Se recomienda un enfoque basado en tareas en los principales documentos rectores, tanto en la enseñanza del inglés en general, como en el contexto de la Educación Primaria, (Marco Común Europeo de Referencia para las Lenguas, 2001; Cameron, 2001; Thomas \& Reinders, (eds.), 2010; Richards y Rodgers, ( $3^{a}$. ed.), 2014; Bygate, M. (2015). Sin embargo, la mayoría de los libros utilizados en las escuelas ofrecen algunas sugerencias de tareas y se centran en actividades más tradicionales para la enseñanza de las lenguas. Como resultado, los profesores tienen un papel muy importante en la aplicación del enfoque basado en tareas. Son responsables por decidir cómo planificar las clases y pensar en cómo hacer los cambios y adaptaciones necesarios para trabajar en una perspectiva basada en tareas.

Palabras Clave: Formación del Profesorado, Enseñanza de las Lenguas basada en Tareas

\section{Introduction}

The recognition of the importance of learning languages to promote plurilingual and pluricultural competences and to foster the acceptance of cultural diversity in a multilingual Europe, has led to the implementation of programs for the learning of English from an early age. Nevertheless, the introduction of the Teaching of English as a compulsory component in Primary Education is quite recent in Portugal, despite the fact that in many European countries English has been taught at this level and even in Pre School education for a few years. 
The Decree Law No. 176/2014 of 12 December introduced the teaching of English in Primary Education in Portugal, from the 3rd year, as a compulsory curricular component. In this way, all students will study English for seven years, from the third to the ninth year, which is the end of basic education. This is what happens in most European countries. In secondary education students may choose to continue studying English but they may also choose a different language.

This law was implemented for the first time in the academic year of 2015/2016. Before that, in 2005, English had been introduced as an extracurricular activity, usually taught in the afternoon after the compulsory subjects. Before 2015, the official start of the teaching of English was in the 5th year, when students are ten years old, which corresponds to the beginning of the second cycle of basic education, in the Portuguese educational system.

The integration of English in Primary Education necessarily required the training of teachers for this new curricular area and level. A new group of recruitment, 120, was created and the professional qualification to teach English in Primary Education was set at the level of a Master's degree, which is a requirement to be a teacher in Portugal, regardless of the level of teaching.

\section{Teaching English in Primary Education - methodological choices}

As a starting point, it is relevant to define the concept of young learners and primary education. In many countries, especially in European contexts, young learners are broadly defined as students between 5 and 12 or 13 years old. Primary education in general lasts for six years, from 6 to 12 which makes the two terms almost synonymous. However, in Portugal primary education lasts 4 years only, from 6 to 10 and that is the context that will be taken into account in this article.

According to Rixon (2018), in most European contexts, Communicative Language Teaching is recommended in the guiding documents for primary school language teaching. Furthermore she states,

It might be more accurate to say that where teaching languages to children has been successful, methodological principles have been developed from experience and have often involved putting good general primary school educational practice to the service of language learning. In these 'child-friendly' approaches, communication and meaningful language use have been dominant without the methodology necessarily aligning itself with mainstream CLT.

Other methodologies frequently used in good language primary teaching are: topicbased, activity based, story-based, fun-based, and CLIL. Task-based language teaching in primary education may aggregate all these methodologies, as their principles are similar. It functions as an umbrella concept that allows all these trends to coexist.

According to Richards, \& Rodgers (2014) Task-Based Language Teaching (TBLT) is more an approach than a method and is characterized by the "use of tasks as the core unit of planning and instruction in language teaching" (p.174).

TBLT is seen as a logical development of Communicative Language Teaching, the innovative approach that revolutionized language teaching in the 1980's, since they share common principles, as stated by Richards \& Rodgers, (2014, p. 174):

- Activities that involve real communication are essential for language learning.

- Activities in which language is used for carrying out meaningful tasks promote learning.

- Language that is meaningful to the learner supports the learning process. 
As the notion of task is central in TBLT, it is important to look at how different authors define tasks:

Nunan (1989, p.10) presents his already classical definition of a task in the following way:

(...) a piece of classroom work which involves learners in comprehending, manipulating, producing or interacting in the target language while their attention is focused on mobilizing their grammatical knowledge in order to express meaning, and in which the intention is to convey meaning rather than to manipulate form. The task should also have a sense of completeness, being able to stand alone as a communicative acts in its own right with a beginning, a middle and na end.

Nunan (1989, cited in Nunan 1999) also makes a distinction between real-world and pedagogical tasks. A great majority of the tasks in a language classroom are pedagogical, for instance,

listening to a weather forecast and deciding what to wear; responding to a party invitation; completing a banking application form; describing a photograph of one's family (pp. 24-25).

Nunan (1999) also distinguishes between a task and an exercise. From his perspective, a task has a non-linguistic outcome, for example choosing the adequate clothes according to a whether forecast. On the other hand, an exercise has a linguistic outcome.

For Richards \& Rodgers (2014:175)

a task is an activity or goal that is carried out using language, such as finding the solution to a puzzle, reading a map and giving directions, making a telephone call, writing a letter or reading a set of instructions and assembling a toy.

Working with children, it is important to consider how the concept of task can be adequate to this age group, as it is not possible to know yet the purposes for which they will be using English in the future. Their communicative needs to use English outside the classroom are also not evident, at least in a context of study where English is only a foreign language, as it happens in Portugal.

The concept of tasks for children suggested by Cameron (2001) is close to the notion of pedagogical tasks defined by Nunan (1989) and summarises the most important features of classroom tasks for children learning a foreign language: They should have:

"coherence and unity for learners (from topic, activity and/or outcome; meaning and purpose for learners; clear language learning goals; a beginning and end and should involve the learners actively". (p.31)

Cameron (2001) considers that a task entails three phases, the preparation, the core activity and the follow-up. The core activity is central to the task and is defined by its language learning objectives. The other two types of activity are described in the following way,

Preparation activities prepare the learners to be able to complete the core activity successfully and might include pre-teaching of language items or activation of topic vocabulary. The follow-up stage builds on successful completion of the "core" perhaps with a public performance of work done in the core or with written work based on oral language used in the core. Since one task can lead to another, the follow-up of the first may be, or lead into, the "preparation" stage of the next. (Cameron, 2001: 32) 
Richards (2016) also answers the question on whether task based language teaching is adequate for teaching children in the following way:

Young learners are more likely to learn through the experience of using the language rather than through studying rules and practising them. This means that their learning will be based on activities and using language that is linked to behaviour, actions and the classroom context. They learn language as it occurs as a part of doing things. (...) Tasks are one kind of activity that can be used successfully with young learners, but many other kinds of activities will also be useful (songs, games, skits and play-related activities). (...) Tasks such as drawing a picture from oral instructions or working in pairs or groups and sequencing a series of pictures to complete a story are effective with young learners.

For Bygate (2015) there are three main approaches to the use of TBLT in language education: the task-supported teaching, the task-referenced approach and the task based approach. The first one means that tasks are added to a language programme that is essentially focused on structures to provide additional communicative use; The second approach uses tasks as a way of defining the target abilities which students are intended to develop by the end of each unit; Finally, according to the third approach, the curriculum and the pedagogic procedures are all designed around tasks. The first two approaches can be considered soft versions of TBLT, while the third one is a hard version of TBLT.

\section{Primary English Education in Portugal}

The Ministry of Education has published several documents with a rationale and guidelines for the teaching of English in primary education. They are: a definition of the essential learning outcomes for the third and the fourth years; The curricular targets, that function as a list of objectives and competences to be achieved as well as a syllabus defining the topics and domains to be studied such as the intercultural domain.

In the definition of the essential learning outcomes for the third year, several purposes are associated to learning a foreign language: Promotes the knowledge of a metalanguage that helps the acquisition of other languages, develops the research capacity, widens the communication competence and interaction with others. It also promotes situations and experiences that develop cognitive competences such as the logical reasoning, critical thinking and creativity in the management of projects and problem solving. It also contributes to the construction of an identity of a global citizen who respects others, and particularly the Anglo-Saxon culture and other cultures in the world.

There are also support documents such as materials and resources with examples to illustrate the implementation of the targets. Some basic principles for teaching English with students at this level are emphasised:

The communication in the classroom should be in English. Students must become familiar with the language so that they will be able understand simple instructions and answer with gestures or words. The mother tongue may be used, but not on a regular basis.

Repetition and routines are fundamental: the repetition of vocabulary, the introduction of routines in the lessons help the learning of vocabulary and structures and promote students' autonomy in the use of English.

The activities should be varied: games, chants, songs, poems, stories and roleplays should be frequently used and involve movement and the five senses.

Whenever possible the activities should integrate contents from other areas of study, for example Maths, science, Arts; 
The resources should be varied and: the learning of the language and or contents through the language should be illustrated with pictures, toys, objects, and if possible with audiovisual resources;

The children must be involved in the production of material, such as posters, cartoons. They may illustrate the contents studied by doing collaborative work with the colleagues.

The Common European Framework of Reference for Languages and a Portuguese version of the European Language Portfolio for Children complete the documents that provide curricular guidelines for teaching English in Primary Education.

These documents follow the European documents on good language teaching practice. Regarding the methodological approach suggested, task-based language teaching is mentioned several times and even considered the norm that all teachers are supposed to know and follow, regardless of their age and qualification. The use of tasks such as creating posters, comic strips role-plays, presenting a pet, writing invitations for parties and several types of pair work is recommended.

We may conclude that these recommendations are not far from the criteria that Rixon (2018) identified, referred to in section 2.

\section{Primary English Education at the University of Algarve.}

The School of Education and Communication of the University of Algarve has been involved in Primary English Education since the 90's of the twentieth century. At that time, the law defined that English and other foreign languages might be taught in Portuguese Primary Schools only if the teachers had knowledge of the language and or if there was any European project which allowed the collaborative work with other countries. Sometimes teachers of English from other levels cooperated with Primary Schools or even parents who were teachers of English could do some occasional cooperation.

Regarding the continuous education of teachers, short courses were offered and attended by several Primary School teachers. Later on, in the early years of the twenty first century, a Postgraduation degree for Primary school teachers who wanted to get the degree of "Licenciatura", functioned for one year with the variety of teaching foreign languages, English and French. In 2005, English started to be taught at all Primary Schools, but as an extra-curricular activity. This meant that English lessons were offered, in the afternoon but they were not compulsory, as students might attend them or not. The teachers did not normally have specific qualifications to work with children.

A syllabus and curricular guidelines with suggestions for planning units of work, activities and materials to be used in the classroom was first published for the third and fourth years, Bento et al (2005), followed by an equivalent publication for the first and second years, Dias \& Toste (2006) by the Ministry of Education.

In 2009, a Postgraduate in Teaching English to Children was approved by the Rector and was offered for three years. At the time, that degree was officially considered adequate professional qualification to teach English at the primary level. As this was a new area in the Primary School context, the law changed several times and, since 2014, a Master's degree is necessary to teach at all levels of the educational system in Portugal, from pre-school to secondary education.

In 2015, English was finally introduced as a new and compulsory component in the Primary Curriculum. Until then, the compulsory components were Portuguese, Maths, Science and Arts. English was introduced for students in the third year in 2015 and in 
2016 for students in the fourth year. Only then did the teaching of English in Portugal equal what was going on for some time already in many countries of Europe. For students in the first and second years English is still taught as an extra-curricular activity.

This change meant that new teachers were needed and had to acquire the adequate specific qualifications. In order to provide enough teachers in such a short time, a new postgraduate degree (Complementos de Formação para Professores de Inglês no $1^{\circ}$ ciclo do Ensino Básico) had to be designed, requalifying teachers of English from other levels or even Primary School Teachers. That degree was offered in 2014/2015 and there were many candidates because the qualification granted access to new teaching posts/vacancies in schools, that were created in that year. The degree functioned in a transition period, before the Master's could produce the new teachers, according to the law.

\section{The Master's degree in Teaching English in Primary Education}

The Master's degree in Teaching English in Primary Education at the School of Education and Communication of the University of Algarve was approved by the accreditation agency A3ES in 2015 and the first edition started in 2016/2017.

The general aims of the degree are:

- To train teachers of English for primary education in such a way as to meet the social, cultural, and linguistic epistemic challenges education is currently facing;

- To ensure pedagogical quality in the teaching profession and, by extension, the quality of the educational system;

- To contribute to educational innovation;

- To promote research in education, with effects on the transformation and improvement of educational practices and of the teaching-learning processes, and to help the school to become a space for sharing and constructing knowledge, and for the promotion of socialization;

- To train new generations of teachers, an essential step for the renewal of the educational system.

Besides these general learning aims, students are expected to develop the following knowledge, skills and competences:

- Acquire knowledge in the area of teaching and of subject-related didactics, as well as strategies required for the construction and renovation of knowledge.

- Learn to do research in education, making use of it for professional purposes, within the scope of the teaching practice;

- Strengthen the ability to work autonomously, as well as the attitude to collaborate and share scientific and professional knowledge in the educational context;

- Learn to adapt principles, concepts, methods and instruments to the teaching-learning process, abiding by the principles of quality assurance and of academic and professional rigour.

- Learn to reflect critically, by means of analysis, interpretation, argumentation and problem-solving strategies, on the ways in which the language functions, and on the most appropriate approaches for its teaching.

- Develop the speaking and writing skills in Portuguese and in English, including academic writing.

The degree comprises three semesters and the main components of the study plan are: English Language, Didactics of English for Children, Materials and Resources, 
Language Learning and Acquisition Principles, Education in Primary Schools, Psychology of Education, Project Development, English Linguistics, British Culture, Introduction to the Professional Practice (IPP) and the Practicum (PES).

The practical components are very important as the students may apply to the Master's without any previous studies in education. What is really necessary is a solid knowledge of English evidenced by the frequency of courses summing eighty ECTS of English or English related topics like linguistics, literature and culture.

Regarding the practical components, in the second semester of the first year students have a course called Introduction to the Professional Practice (IPP). They go to a Primary School and observe lessons for 6 weeks. In the first semester of the second year of the degree they have the Practicum. It develops for a complete semester and students have to plan and teach English lessons to a third and a fourth year class. The class teacher is always present during the lessons and helps the trainee with the planning and implementation of the lessons/activities. There is also a supervisor from the university that guides students and watches some lessons and gives feedback to the students.

Both during the Introduction to the Professional Practice and the Practicum the European Portfolio for Student Teachers of English is used as a reference document. It helps them focus on what to observe in the lessons and later on to plan their teaching, to evaluate and reflect on their lessons.

At the heart of the EPOSTL are the 193 descriptors of competences related to language teaching which comprise the self-assessment section. These descriptors may be regarded as a set of core competences which language teachers should strive to attain. (Newby, 2007, p. 5)

\section{Observations from the Practicum}

So far, in the academic year of $2017 / 2018$, the Practicum took place in seven different schools in the Algarve, most of them state schools, but also including a private school. The curricula in Portugal are designed at national level, but each school and school cluster designs an educational project which allows some adaptation of the national guidelines to the local context, catering for the characteristics and needs of the students.

English is taught twice a week, in 45-minute lessons to the third and fourth year students who are normally 8 to 10 years old. The English lessons most of the time, "interrupt" the work with the class teacher, or sometimes happen first thing in the morning or late in the afternoon. As already stated by Orega \& Lopes (2018), the teachers of English do not work in a single school and frequently have to travel between schools on the same day. This means that when they finish a lesson, they have to travel several kilometres to go to a different place for the following lesson. Consequently, there is not much time for the class teachers and the teachers of English to work together along the school year. So, unless the planning and coordination is agreed at the beginning of the school year, or at the beginning of each term, it simply doesn't exist. In some extreme cases, the English teacher walks in the classroom for the lesson and the class teacher walks out to enjoy a 45-minute break to do something else. There simply isn't no time allowed for the joint planning of lessons or activities. Everything that is done in that perspective is an individual effort of the teachers who sacrifice their personal time for the sake of the students.

The suggestions for using a CLIL approach are thus difficult to implement, as it was stated by Orega and Lopes (2018b). They developed a study with the following aims: 
Characterize attitudes and perceptions of EFL teachers and Primary School teachers concerning the teaching of English in primary education; Characterize their attitude towards collaborative work; Learn about objective and subjective conditions for collaborative work between EFL and PS teachers; Provide suggestions to enhance collaborative work (including CLIL). Both English Language Teachers and Primary school teachers are available to cooperate and agree that developing joint projects is a good solution to integrate different components of the curriculum. Nevertheless, these ideas are very difficult to implement because of the working conditions of the English Teacher who frequently has to travel to another school to complete his daily timetable.

As it was explained in section 4, the Portuguese national curriculum guidelines are quite detailed and complete.

However, with the hectic life and the occupation of the English teachers, not many have enough time to read the curricular guidelines and so the coursebooks take a very important role, as they end up as the most important referential. Coursebooks for Primary English appeared in the Portuguese market since 2015 and thrived as this new niche was quickly explored by the publishers. Nowadays, most of them offer at least one coursebook for the third and the fourth years as well as activity books, flashcards, CDs and several other materials for this age level. The coursebooks have all supposedly been written according to the curricular targets (Metas curriculares), and provide teacher's books with detailed unit and term plannings, as well as several resources, to be used in different media. That's fine, the competition among publishers provides teachers with several coursebooks to choose from.

The coursebooks, in general, offer an instrumental interpretation of the targets, focusing essentially on developing the four skills in a relatively integrated way. However, a task, as the product to achieve at the end of the unit, is not frequently identified.

\section{Towards a Task-based approach - the role of the teacher}

Most teachers feel pressured to use the coursebook and complete it until the end of the school year. Parents have bought the coursebooks and consider that they should be used. Teachers are also quite busy and don't always have the time to think of alternatives to the materials and activities offered ready made by the coursebook.

The solution to help the implementation of a task-based approach to teaching English in primary education is on the approach to planning the units of work. These sequences have to be designed in a way that all the work developed along the unit produces a final task, that calls students attention and provides a purpose for learning. The focus is not on aspects of form, but on meaning. At the end of the unit students will be able to do something that they couldn't do before.

Tasks also provide ways of integrating English with the other areas of the curriculum, for example Maths, Science or Music. The Primary curriculum offers a naturally adequate context to integrate skills and curriculum components. Planning task-based work or even project-based work is a good way to articulate curricular content and the work of both the class teacher and the English teacher.

As to the types of learning and teaching activities, Van den Branden (2006) cited in Richards \& Rodgers (2014:187-188) lists several roles for teachers in TBLT,

- Motivate the students to invest mental energy in task performance, and to support their level of motivation through the various phases of a task-based activity.

- Efficiently organize the task-based activity, for instance by giving clear instructions and preparing the students for task performance, guiding the formation of groups (for group work) making sure that students have all the 
material necessary for task completion or are informed about the ways they can obtain these materials.

- Interactionally support the students while they are performing the task, and differentiate between students (or students groups) while doing so.

Nassa (2018), developed a small scale research on teachers perceptions of teaching methods, particularly of TBLT, to find out their main teaching practices. She designed a survey that was delivered on the internet, among teachers groups and mailing lists. She got 35 respondents from different parts of Portugal. It's important to highlight that Nassa was a student of the Master's degree in Teaching English in Primary Education at the School of Education and Communication of the University of Algarve. She was the first student to finish her research that is part of her Practicum Report and the final task to complete the degree. Nassa (2018:34) found out that,

Although teachers recognize TBLT as an interesting and stimulating teaching approach, that promotes creativity, interaction, autonomy and motivation of the learners, factors like class size, behaviour issues, short time to accomplish the Curricular Targets are understood as constraints that limit the frequency of TBLT adoption.

The results of her study are similar to the ones described by several authors that she reviews. She also found out that teachers are eclectic in the methods, materials and activities selected. TBLT is definitely considered a useful and effective approach, despite the fact that it is not very frequently used because of several constraints. When you work with children, it is important that teachers may choose activities and content that are appropriate for the children's age, and sociocultural experience. They should also choose language that "will grow with the children" (Nassa, 2018:35)

Perhaps we may go back to the ideas presented by Bygate (2015). What happens in Portugal, according to the respondents to the survey in Nassa's research may be described more accurately as a task-supported approach. Tasks are used to provide a more communicative practice in the lessons, but the unit and lesson planning is still essentially focused on structures or vocabulary.

We may conclude that this is the approach most frequently identified in coursebooks.

\section{Examples}

The examples of tasks presented below were all successfully implemented during the Practicum in 2017/2018. The first one was used at the end of a unit on numbers. Students did a survey on the number of brothers and sisters of each colleague. After gathering the results, they built a chart with the pictures of the students organised according to the number of siblings. Figure 1 shows what the chart looked like, posted on one of the walls of a third year classroom. Students were very motivated to see their picture on the poster and to understand that they have contributed to that group task, now decorating the classroom. The sense of authenticity associated to tasks is a powerful motivation that doesn't exist associated to a plain language exercise. 


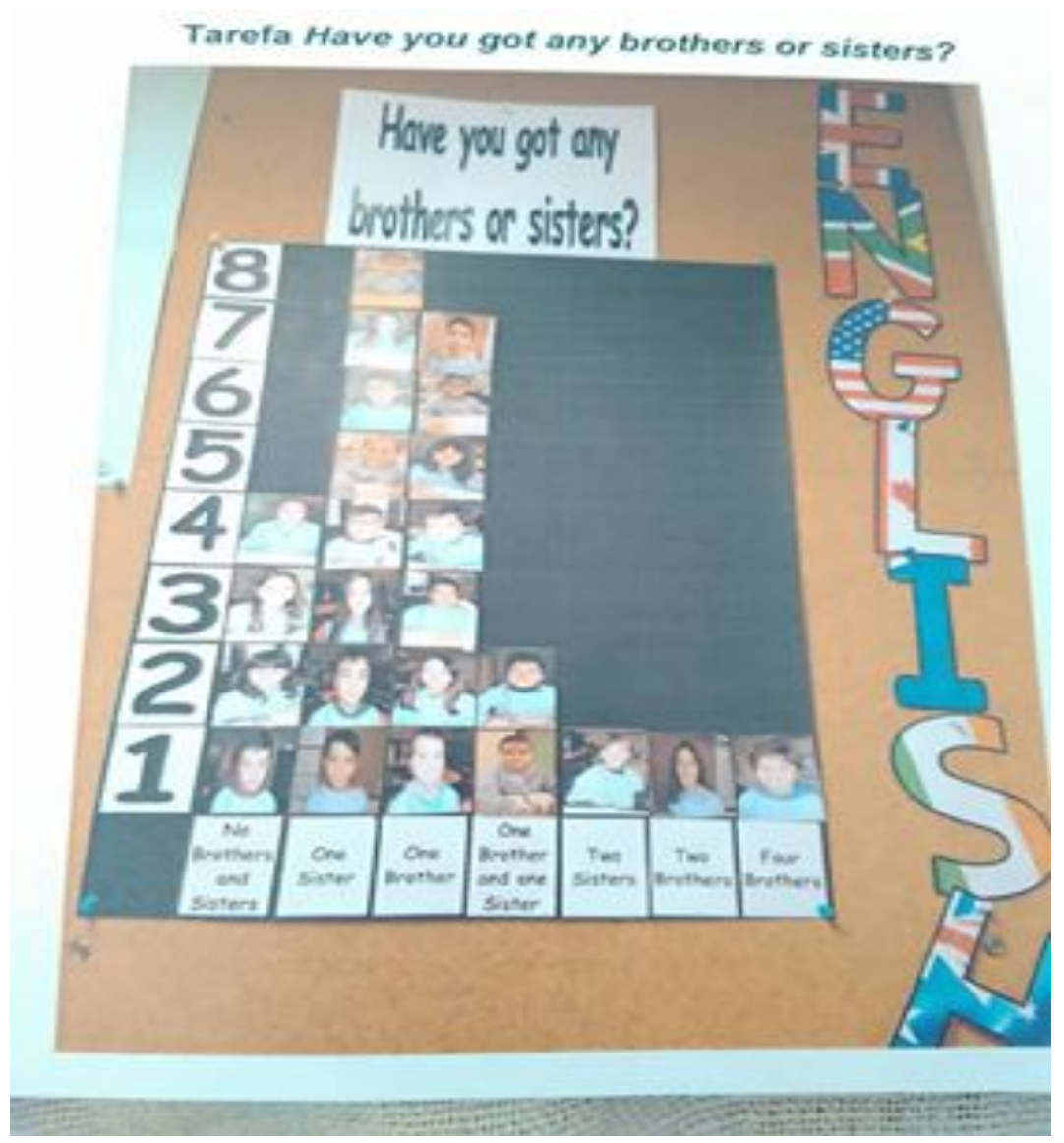

Fig. 1 Chart with the number of brothers and sisters

A second example is the task defined to be completed at the end of a unit on school objects. The vocabulary on classroom language and school objects is necessary on a daily basis and a unit on this topic is part of the third year syllabus. Students had to select three favourite school objects, and present a school bag made of cardboard and the three favourite school objects to the class. When students have to show personal preferences and are free to select the objects that they like most, motivation is normally guaranteed.

Stories are a rich resource and allow many different activities and or tasks based on them. This time the story selected was the well known The Very Hungry Caterpillar by Eric Carle. The story may be exploited in different ways. This time, with a class of third year students, at the end of the unit after the story was read several times and studied, students produced a mini-book with a summary of the story, completed and coloured it. At the end of the lesson, most of the students wanted to take the mini-book home to show it to their parents. The awakening of the sense of authorship is a fundamental way to develop writing skills and to convey the idea that texts are written for an audience.

These are very simple tasks, most of them were done with a third year class in the first term, at a time when they had had only few lessons of English. The examples evidence that it is possible to use tasks even with absolute beginners. Sometimes the teachers think that tasks are more adequate for older students but it is not true. The use of tasks is a question of approach to teaching that will imply a particular way of planning and thinking about what to do with the students. Of course tasks have to be chosen in order to motivate the younger children but if they are adequate to their age and competences, students will love to learn and are normally very enthusiastic about being able to do new things. 


\section{Conclusion}

We may conclude that all the examples presented are student-centered and contain a way to make them talk about their interests, motivations or aspects of their life, like the family. The tasks don't have to be complicated, as the examples above illustrate. What is essential is the approach and the methodology that focuses on learning the language by doing "things" that are interesting and adequate to the age and interests of the learners. The formal aspects selected are the ones that are necessary to accomplish the tasks and are not the main focus of the unit/lesson or the starting point of the planning done by the teacher. Teachers do not select a grammar aspect, like a verb tense or the degrees of the adjectives to organise a unit of work. Instead they decide on what students will be able to do at the end of the teaching sequence, and then see what language is necessary to accomplish it.

The teachers have a key role in introducing the necessary changes to implement a taskbased approach in Primary Education. They have a fundamental role as curriculum developers. As Richards \& Rodgers (2014) state, the level of procedure is the level of implementation in the classroom of what was defined at previous levels like curriculum design and the definition of content to be taught, but also of how to teach. Teachers should not only be practitioners who implement what was designed at national level by the experts in curriculum development. In their education degrees, they have to learn the methodological principles that justify a rationale for the practice. This means that they will look at a coursebook with a critical perspective and they will be able to complement it, if the coursebook doesn't quite answer the requirements of the task-based approach. In general, coursebooks need to be supplemented with other materials and the suggestions for planning do not need to be followed exactly as the coursebook suggests, as there should be space for the creativity of the teacher.

In this way, teacher education is crucial in order to guarantee that teachers are able to critically evaluate the suggestions presented in a coursebook and supplement them if necessary.

The Master's degree in Teaching English in Primary Education is already contributing to improve this new area of Primary English Education in Portugal. We have concluded a first edition of the Master's and in the academic year of 2018/2019 we have already started a second edition. As the study by Nassa (2018) reveals, the teachers, by concluding this degree, have to perform a small scale research project. In this way, they develop investigation competences which contribute to the development of an inquiring mind and to be curious about implementing action research in their teaching contexts in order to solve any existent problems or difficulties.

\section{References}

Andrade, A. I. \& Martins, F. (coord.) (2007). Abordar as línguas, integrar a diversidade nos primeiros anos de escolaridade. Cadernos do LALE. Aveiro: Universidade de Aveiro.

Bento, C., Coelho R., Joseph, N. Mourão S. (2005). Programa de Generalização do Ensino de Inglês no $1^{\circ}$ Ciclo do Ensino Básico, Orientações Programática e Materiais para o Ensino e Aprendizagem. Lisboa: Ministério da Educação. Retrieved from https://www.dge.mec.pt/sites/default/files/Basico/AEC/ensino ingles $3 \mathrm{e} 4$ anos.p df 
Bravo C., Cravo A. \& Duarte E. (2015). Metas Curriculares de Inglês. Ensino Básico: $1^{\circ}$ Ciclo. Caderno de Apoio. Lisboa: Ministério da Educação e Ciência. Retrieved from

http://www.dge.mec.pt/sites/default/files/Basico/Metas/ING/caderno apoio ingles 1 ceb.pdf

Bravo C., Cravo A., \& Duarte E. (2015). Metas Curriculares de Inglês. Ensino Básico: $1^{\circ}$ Ciclo. Lisboa: Ministério da Educação e Ciência. Retrieved from http://www.dge.mec.pt/sites/default/files/Basico/Metas/ING/eb metas curriculare s ingles.pdf

British Council, A Task-based approach. Retrieved from https://www.teachingenglish.org.uk/article/a-task-based-approach.

Burns, A. (1999) Collaborative Action Research for English Language Teachers. Cambridge:

Bygate, M. (2015). Sources, Developments and Directions of Task-based language teaching. The Language Learning Journal. 44:4. Retrieved from https://www.tandfonline.com/doi/abs/10.1080/09571736.2015.1039566?journalC ode $=$ rllij20

Cambridge University Press.

Cameron, L. (2001). Teaching Languages to Young Learners. Cambridge: Cambridge University Press.

Council of Europe (2001). Common European Framework of Reference for Languages. Cambridge: Cambridge University Press.

Dias, A. \& Toste, V. (2006). Ensino do Inglês $1^{\circ}$ ciclo do ensino básico Orientações programáticas $1^{\circ}$ e $2^{\circ}$ anos. Lisboa, Ministério da Educação. Retrieved from https://www.dge.mec.pt/sites/default/files/Basico/AEC/ensino ingles $1 \mathrm{e} 2$ anos.p df.

Direção Geral de Educação (2012) O Meu Primeiro Portefólio Europeu de Línguas. Retrieved from http://www.dge.mec.pt/sites/default/files/ficheiros/portefolioeuropeu 1ciclo.pdf

Direção Geral de Educação (2018). Aprendizagens Essenciais, $1^{\circ}$ ciclo do Ensino Básico, Inglês, $3^{\circ}$ ano. Retrieved from http://www.dge.mec.pt/sites/default/files/Curriculo/Aprendizagens Essenciais/1 c iclo/ingles 1c 3a ff.pdf

Direção Geral de Educação (2018). Aprendizagens Essenciais, $1^{\circ}$ ciclo do Ensino Básico, Inglês, $3^{\circ}$ ano. Retrieved from http://www.dge.mec.pt/sites/default/files/Curriculo/Aprendizagens Essenciais/1 c iclo/ingles 1c 4a ff.pdf

Estaire, S. \& Zañon, J. (1994). Planning Classwork: The Task-based Approach. Oxford: Heinemann.

Fenner, A-B, Jones, B., Newby, D. (2011). Using the European Portfolio for Student Teachers of Languages. Retrieved from https://www.ecml.at/Resources/ECMLPublications/tabid/277/ID/24/language/enGB/Default.aspx

Fenner, A-B, Jones, B., Newby, D. (2011). Using the European Portfolio for Student Teachers of Languages. Retrieved from https://www.ecml.at/Resources/ECMLPublications/tabid/277//D/24/language/enGB/Default.aspx

Garton, S. (Ed.), Copland, F. (Ed.). (2019). The Routledge Handbook of Teaching English to Young Learners. London: Routledge. 
González-Lloret, M. (2016) A Practical Guide to Integrating Technology into Task-based Language Teaching. Georgetown: Georgetown University Press.

Inglês no $1 .^{\circ}$ Ciclo do Ensino Básico. SENSOS-e, Vol 5 No 1 (2018): PEEP'17 - Primary English Education in Portugal, pp. 149-174.

Nassa, S. (2018). Task-based Language Teaching in the Portuguese Primary Education Teacher's perceptions and practices. Unpublished Master's Final Report. Escola Superior de Educação e Comunicação, Universidade do Algarve.

NCE/14/02186 - Apresentação do pedido - Novo ciclo de estudos (2015). Escola Superior de Educação e Comunicação, Universidade do Algarve.

Newby, D., Allan, R., Fenner, A.B., Jones, B. Komorowska, H. and Soghikyan, K. (2007) The European Portfolio for Student Teachers of Languages (EPOSTL). Retrieved from https://www.ecml.at/Portals/1/documents/ECML-resources/EPOSTLEN.pdf?ver=2018-03-22-164301-450

Nunan, D, (1989). Designing Tasks for the Communicative Classroom. Cambridge: Cambridge University Press.

Nunan, D. (1999). Second Language Teaching and Learning. Boston: Heinle \& Heinle Publishers.

Orega, M. I. \& Lopes, A. (2018) Motivação para o trabalho colaborativo na aula de

Orega, M. I. \& Lopes, A. (2018b). Conditions of Possibility of CLIL in Algarve's Primary Schools. Poster presented at the PEEP Meeting 2018, Lisboa, Instituto de Educação da Universidade de Lisboa.

Richards, J. C. (2016). Task-based Teaching in Primary School. Retrieved from https://www.professorjackrichards.com/task-based-teaching-in-primary-school/.

Richards, J.C. \& Rodgers, T. S. (3rd. ed.), (2014). Approaches and Methods in Language Teaching. Cambridge: Cambridge University Press.

Rixon, S. (2018). Teaching English to young learners in Europe. In Garton, S. (Ed.), Copland, F. (Ed.) The Routledge Handbook of Teaching English to Young Learners. London: Routledge.

Shintani, N. (2016). Input-based Tasks in Foreign Language Instruction for Young Learners. Amsterdam: John Benjamins Publishing Company.

Thomas \& Reinders (eds.), 2010. Task-Based Language Learning and Teaching with Technology. London: Continuum. 